\title{
Vascular Endothelium
}

Physiological Basis

of Clinical Problems 


\section{NATO ASI Series}

\section{Advanced Science Institutes Series}

A series presenting the results of activities sponsored by the NATO Science Committee, which aims at the dissemination of advanced scientific and technological knowledge, with a view to strengthening links between scientific communities.

The series is published by an international board of publishers in conjunction with the NATO Scientific Affairs Division
A Life Sciences
B Physics
C Mathematical and Physical Sciences
D Behavioral and Social Sciences
E Applied Sciences
F Computer and Systems Sciences
$G$ Ecological Sciences
H Cell Biology
I Global Environmental Change

\author{
Plenum Publishing Corporation \\ New York and London \\ Kluwer Academic Publishers \\ Dordrecht, Boston, and London \\ Springer-Verlag \\ Berlin, Heidelberg, New York, London, \\ Paris, Tokyo, Hong Kong, and Barcelona
}

Recent Volumes in this Series

Volume 202-Molecular Aspects of Monooxygenases and Bioactivation of Toxic Compounds edited by Emel Arınç, John B. Schenkman, and Ernest Hodgson

Volume 203-From Pigments to Perception: Advances in Understanding Visual Processes edited by Arne Valberg and Barry B. Lee

Volume 204-Role of Melatonin and Pineal Peptides in Neuroimmunomodulation edited by Franco Fraschini and Russel J. Reiter

Volume 205-Developmental Patterning of the Vertebrate Limb edited by J. Richard Hinchliffe, Juan M. Hurle, and Dennis Summerbell

Volume 206-Alcoholism: A Molecular Perspective edited by T. Norman Palmer

Volume 207-Bioorganic Chemistry in Healthcare and Technology edited by U. K. Pandit and F. C. Alderweireldt

Volume 208-Vascular Endothelium: Physiological Basis of Clinical Problems edited by John D. Catravas, Allan D. Callow, C. Norman Gillis, and Una S. Ryan

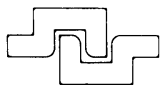

Series A: Life Sciences 


\section{Vascular Endothelium \\ Physiological Basis of Clinical Problems}

Edited by

\section{John D. Catravas}

Medical College of Georgia

Augusta, Georgia

\section{Allan D. Callow}

Washington University Medical Center

St. Louis, Missouri

\section{Norman Gillis}

Yale University

New Haven, Connecticut

and

Una S. Ryan

Monsanto Company

St. Louis, Missouri 
Proceedings of a NATO Advanced Study Institute on

Vascular Endothelium: Physiological Basis of Clinical Problems,

held June 18-28, 1990,

in Corfu, Greece

Library of Congress Cataloging in Publication Data

NATO Advanced Study Institute on Vascular Endothelium: Physiological Basis of Clinical Problems (1990: Kerkyra, Greece)

Vascular endothelium: physiological basis of clinical problems / edited by John D. Catravas ... [et al.].

p. $\quad$ cm.-(NATO ASI series. Series A, Life sciences; v. 208)

"Proceedings of a NATO Advanced Study Institute on Vascular Endothelium: Physiological Basis of Clinical Problems, held June 18-28, 1990, in Corfu, Greece"-T.p. verso.

"Published in cooperation with NATO Scientific Affairs Division."

Includes bibliographical references and index.

ISBN 978-1-4613-6663-8 ISBN 978-1-4615-3736-6 (eBook)

DOI 10.1007/978-1-4615-3736-6

1. Vascular endothelium-Pathophysiology-Congresses. I. Catravas, John D. II. North Atlantic Treaty Organization, Scientific Affairs Division. III. Title. IV. Series.

[DNLM: 1. Endothelium, Vascular-physiology-congresses. QS 532.5.E7 N279va 1990]

RC691.4N38 1990

$616.1 / 3-d c 20$

DNLM/DLC

$91-24022$

for Library of Congress

CIP

ISBN 978-1-4613-6663-8

(C) 1991 Springer Science+Business Media New York

Originally published by Plenum Press, New York in 1991

Softcover reprint of the hardcover 1st edition 1991

All rights reserved

No part of this book may be reproduced, stored in a retrieval system, or transmitted in any form or by any means, electronic, mechanical, photocopying, microfilming, recording, or otherwise, without written permission from the Publisher 


\section{PREFACE}

This monograph contains the proceedings from the Advanced Study Institute on "Vascular Endothelium: Physiological Basis of Clinical Problems" which took place in Corfu, Greece in June 1990. The meeting consisted of twenty-eight lectures, most of them adapted as full length papers in this volume, as well as numerous short oral and poster communications which are abstracted and also included in alphabetical order (pages 239-302). There were ninety-six participants from ten NATO and four other European countries. The meeting was the second in as many years dealing with a specific subject in Endothelial Cell biology. Following the 1988 discussion on "Receptors and Transduction Mechanisms", the present ASI recognized and tried to deal with the increasing overlap in interest between basic scientists studying endothelial cell functions and clinicians facing problems of known or suspected endothelial pathological involvement. As with any similar effort, we opted to be selective, rather than fail by trying to be inclusive, in the subjects covered. We chose to discuss diseases, such as atherosclerosis, sepsis, ARDS and stroke, based on their relevance to endothelial cell function and urgent need for new insights into their pathogenesis and treatment. Similarly, we examined endothelial cell functions by considering their relevance to disease and their potential for elucidating important pathologies. Obviously, some areas were covered superficially or not at all; this should not distract from their importance, but rather reflect on the constraints of time and - not at all negligibly - the bias of the organizing committee.

As a product of the Advanced Study Institute, this book is the result of efforts by many individuals. The International Organizing Committee, composed of the Co-Directors, Dr. Alberto Mantovani (Italy), Dr. Salvador Moncada (U.K.) and Dr. Magdi Yacoub (U.K.), put together the scientific program and selected the Lecturers, each one of whom was kind enough to generously offer time and expertise. The Local Organizing Committee, composed of Drs. Orfanos and Maragoudakis and Ms. Lydia Argyropoulos, assumed numerous important responsibilities, relating to both the scientific aspects as well as the arrangement of local facilities, necessary for the smooth execution of the conference. Dianne Rosenquist was again the Co-ordinator of the ASI who maintained order ably and cheerfully and seemed unflappable at the sight of chaos. As in 1988, Mary Ann Roupp diligently and enthusiastically processed all manuscripts and abstracts, provided original contribution towards the style of the book and, with the help of Jim Parkerson, Connie Snead, Adrienne Grzeskiewicz, Stavros Topouzis, Nandy Marczin and Stelios Orfanos, proof read the entire text. To all these individuals, we are deeply grateful. Lastly, and perhaps most importantly, we express our sincere appreciation to all participants, whose interest in the field of Endothelial Biology and active participation assured the success of this meeting and who were gracious enough to write or call with flattering comments.

John D. Catravas (Augusta)

Allan D. Callow (St.Louis)

C. Norman Gillis (New Haven)

Una S. Ryan (St. Louis) 


\section{CONTENTS}

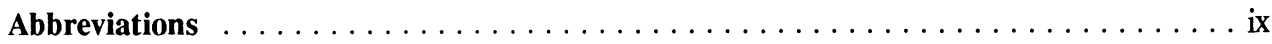

\section{CLINICAL TOPICS}

The Clinical Profile of Sepsis and the Adult Respiratory Distress

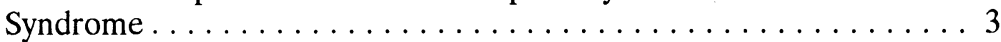

Kenneth L. Brigham

The Participation of the Complement System in Atherosclerotic Vascular

Disease ........................... 13

Paul S. Seifert, S. Bhakdi and M.D. Kazatchkine

The Spectrum of Atherosclerosis in the Human . . . . . . . . . . . 27

Allan D. Callow

Cerebral Endothelial Injury in Stroke, Brain Trauma and Hypertension . . . . . 47 Hermes A. Kontos

\section{GENERAL CONCEPTS IN ENDOTHELIAL CELL PATHOPHYSIOLOGY}

Free-Radical Mediated Actions on Endothelial Cells of the Intact Lung . . . . 55 C. Norman Gillis, X. Chen and M. Merker

Regulation of Vascular Function by Vascular Permeability Factor 69 Daniel T. Connolly

\section{CHEMICAL MEDIATORS OF ENDOTHELIAL CELL INJURY}

Endothelial Cells as Targets for and Producers of Cytokines . . . . . . . . . . 79 E. Dejana, G. Bazzoni, I. Martin-Padura, S. Walter and Alberto Mantovani

Roles of Vascular Cells in Inflammation and Immunopathology $\ldots \ldots \ldots \ldots 87$ Peter Libby

The Biochemistry, Cell and Molecular Biology of Type 1 Plasminogen Activator Inhibitor $\ldots \ldots \ldots \ldots \ldots \ldots \ldots \ldots \ldots \ldots \ldots \ldots \ldots \ldots \ldots \ldots$ David J. Loskutoff

\section{ENDOTHELIAL CELL INTERACTION WITH BLOOD COMPONENTS}

Purine Regulation of Endothelial Cells: Relevance to Pathophysiology John L. Gordon 
Leukocyte-Endothelial Cell Interactions James Varani

\section{VASCULAR RESPONSES TO ENDOTHELIAL CELL INJURY}

Endothelial Function in Human Coronary Bypass Grafts

Thomas F. Lüscher and Z. Yang

Altered Renovascular Endothelial Functions During Nephrotoxicity

N. Perico, C. Zoja and Giuseppe Remuzzi

Cerebral Endothelial Function: Physiology and Pathophysiology

Donald D. Heistad, F. Faraci, and G. Baumbach

Mechanisms of Altered Reactivity in the Cerebral Microcirculation

175 Hermes A. Kontos

\section{MECHANISMS OF ENDOTHELIAL CELL DYSFUNCTION}

The Role of Apolipoprotein E and Apolipoprotein B in

Atherosclerosis

Thomas L. Innerarity

Endothelial Cell-Matrix Interactions in Health and Disease

Elisabetta Dejana, A. Zanetti, C. Dominguez-Jimenez and G. Conforti

Biosynthesis and Assembly of von Willebrand Factor by Vascular Endothelial

Cells: Relevance to Pathophysiology . . . . . . . . . . . . . . . 203 Jan A. van Mourik

\section{MARKERS OF ENDOTHELIAL CELL INJURY AND REPAIR}

Monitoring of Endothelial Plasmalemmal Ectoenzyme Function as an Index of Endothelial Injury and Repair . John D. Catravas

Pathophysiological Significance of Endothelial Cell Integrins 225 Jan A. van Mourik, Jacques G. Giltay and Albert E.G. Kr. von dem Borne

\section{EPILOGUE}

Vascular Endothelium: Physiological Basis of Clinical Problems 233 Kenneth L. Brigham 


\section{ABBREVIATIONS}

$\beta$-VLDL

15-HPETE

5-HIAA

5-HT

ACE

ACh

ADP

AECA

Al

All

apo-B100,B48,-E,-E3,-E4

BAE

BBB

bFGF

BK

BSA

CHD

CR

CVD

CyA

DAF

DMEM

EC

ECM

EDCF

EDRF

ELAM

ELISA

FDB

$\mathrm{FH}$

G-CSF

GFR

GLUT-1,-4

GM-CSF

HPLC

HR

HRF

HUE

HUS beta-very low density lipoprotein

15-hydroperoxyeicositetraeinoic acid

5-hydroxyindoleacetic acid

serotonin, 5-hydroxytryptamine

angiotensin converting enzyme

acetylcholine

adenosine $5^{\prime}$-diphosphate

anti-endothelial cell antibodies

angiotensin I

angiotensin II

apolipoprotein-B100,B48,-E,-E3,E4

bovine aortic endothelial

blood-brain barrier

basic fibroblast growth factor

bradykinin

bovine serum albumin

coronary heart disease

complement receptors

cardiovascular disease

cyclosporine $\mathrm{A}$

decay-accelerating factor

defined minimum essential medium

endothelial cells

extracellular matrix

endothelium-derived constricting factor

endothelium-derived relaxing factor

endothelial-leukocyte adhesion molecule

enzyme linked immunosorbent assay

familial defective apo-B100

familial hypercholesterolemia

granulocyte-colony stimulating factor

glomerular filtration rate

glucose transporter isotype

granulocyte-macrophage-colony stimulating factor

high pressure liquid chromatography

heart rate

homologous restriction factors

human umbilical vein endothelial cells

hemolytic-uremic syndrome 
ICAM

IDL

IFN

$\lg E, G, M$

IL-1,-6

L-NMMA

LDL

LFA

LPS

MAb

MAO

MCP

MEL

NAP

NO

PA

PAF

PAI-1

PAI-2

PCR

PDGF

$\mathrm{PGH}_{2}$

$\mathrm{PGI}_{2}$

PMA

PR

RR

SDS-PAGE

SHRSP

SLE

SNP

SOD

t-PA

TG

TGF

TIAs

TNF

TTP

$\mathrm{TxA}_{2}, \mathrm{~B}_{2}$

u-PA

VCAM

VEGF

VLDL

$\mathrm{Vn}$

VPF

WWF

WHHL

WKY intercellular adhesion molecule

intermediate density lipoprotein

interferon

immunoglobulin E,G,M

interleukin-1,-6

L-N-mono-methylarginine

low density lipoprotein

leukocyte function associated molecule

lipopolysaccharide

monoclonal antibodies

monoaminooxidase

membrane cofactor protein

mouse endothelial lectin

neutrophil activating protein

nitric oxide

plasminogen activator

platelet activating factor

type 1 plasminogen activator inhibitor

type 2 plasminogen activator inhibitor

polymerase chain reaction

platelet-derived growth factor

prostaglandin $\mathrm{H}_{2}$

prostaglandin $\mathrm{I}_{2}$, prostacyclin

phorbol myristate acetate

pulse rate

respiratory rate

sodium dodecyl sulfate-polyacrylamide gel electrophoresis

stroke-prone spontaneously hypersensitive rats

systemic lupus erythematosus

sodium nitroprusside

superoxide dismutase

tissue type-PA

triglycerides

transforming growth factor

transient ischemic attacks

tumor necrosis factor

thrombotic thrombocytic purpura

thromboxane $A_{2}, B_{2}$

urokinase-type-PA

vascular cell adhesion molecule vascular endothelial growth factor very low density lipoprotein vitronectin

vascular permeability factor von Willebrand factor

Watanabe heritable hyperlidemic Wistar-Kyoto 